This item was submitted to Loughborough's Research Repository by the author.

Items in Figshare are protected by copyright, with all rights reserved, unless otherwise indicated.

\title{
Negotiating the responsibilities of collaborative undergraduate fieldcourses
}

PLEASE CITE THE PUBLISHED VERSION

https://doi.org/10.1111/area.12192

\section{PUBLISHER}

Wiley @ Royal Geographical Society (with the Institute of British Geographers)

\section{VERSION}

AM (Accepted Manuscript)

\section{PUBLISHER STATEMENT}

This work is made available according to the conditions of the Creative Commons Attribution-NonCommercialNoDerivatives 4.0 International (CC BY-NC-ND 4.0) licence. Full details of this licence are available at: https://creativecommons.org/licenses/by-nc-nd/4.0/

\section{LICENCE}

CC BY-NC-ND 4.0

\section{REPOSITORY RECORD}

Bhakta, Amita, Jen Dickinson, Kate Moore, David Mutinda, Anna Mylam, and Caroline Upton. 2019. "Negotiating the Responsibilities of Collaborative Undergraduate Fieldcourses". figshare. https://hdl.handle.net/2134/36392. 


\section{Negotiating the responsibilities of collaborative undergraduate fieldcourses}

\section{Introduction}

Fieldcourses to destinations in the global South continue to be a fundamental component of British undergraduate degree programmes, despite recent concerns over the demise of long-haul fieldtrips more broadly (Herrick, 2010). As well as offering complex environments that facilitate cognitive learning and skills acquisition, undergraduate fieldcourses present opportunities for students to understand, interpersonally, the perspectives of those experiencing particular development challenges, rather than these being presented as abstract distanciated objects of learning and study (Robson, 2002). They also provide important opportunities for co-learning and reflexivity. However, the continued use of such fieldcourses has opened up a number of critical debates about their lasting consequences for local host communities (Hammett and Sporton, 2012) and the neo-colonial relationships of dependency they arguably perpetuate (Abbott 2007). Nonetheless, and despite such concerns, pressing questions of academic responsibility continue to receive somewhat less attention than more vociferous debates around the pedagogies and practicalities of global South fieldcourses (see for example, Winlow et al 2007, Glass 2014, Hill et al 2008, McGuiness and Sim 2005). In this paper we seek to begin to redress the balance, through critical reflection on a recent Kenyan fieldcourse with which all the authors were closely involved, albeit in diverse roles. Specifically, we explore the potential of such collaborative fieldcourses, and the multidimensionalities of responsibility embedded therein, for challenging some of the ongoing power asymmetries of acquisitive knowledge production in Western academic institutions. Exploring responsibility from the perspective of undergraduate fieldwork, we argue, offers an opportunity to connect understandings of the academic politics of responsibility to the emotional, embodied and affective challenges inherent in practicing collaborative academic endeavor

\section{Negotiating 'responsibility' in participatory fieldwork}

Collaborative fieldcourses have begun to gain traction within undergraduate 
programmes as a way of allowing for the possibility of dialogical, negotiated and inter-cultural learning in a way that benefits both students and local communities (Pain et al 2012, McEwen 2013, Hammersley et al 2014). For example, Robson and Willis' (2013) recent report for the Higher Education Authority on fieldcourses in the global South highlights collaboration as integral aspects of 'best practice', through development of reciprocal teaching relationships that specifically "avoid... retrenching Northern-centric assumptions" ( $p$ 9). The shift towards collaborative fieldcourse teaching emanates, broadly speaking, from scholars' growing ethical concern with the unequal global power differentials within which scholarly endeavor operates (Valentine 2005), particularly as it relates to geography's (post)colonial disciplinary positionings within distanciated North-South relations (Sidaway 1992). A responsible 'engaged pedagogy' (hooks 1994) built upon an openness that scrutinizes, but also transcends, distanciated knowledge production in these disciplinary contexts requires a more 'care-full' teaching approach centered on fostering participation, intimacy and encounter across difference (Newstead 2009).

Within wider debates about how geographers can enact a more care-full academic praxis (Lawson 2007), the notion of academic responsibility has come to occupy a significant aspect of recent debate, particularly around the extent to which collaborative field research can allow academics to exercise responsibility to the people and places we research (Nagar and Ali 2003, Cameron \& Gibson 2005, Kindon et al., 2009, Moseley 2007). A series of questions has arisen around balancing responsibility to local communities and partners with the continued strictures posed by the political and institutional contexts of academic research built, conducted and assessed on resourcing metrics (De Leeuw et al 2011, Pickerill 2008). Whilst this scholarship highlights some of the institutional challenges that might be posed to achieving the wider aims of collaborative fieldcourse teaching, what is needed, we argue here, is a more nuanced understanding of 'responsibility' itself. For Noxolo et al (2012), 'responsibility' is very often conceived of on behalf of distant others and therefore reinforces boundaries between self/other and here/there. As geographical research in a number of contexts has shown (e.g. Mostafanezhad 2013, McEwan and Goodman 2010) the care-full enactment of responsibility is an inherently unequal endeavor since, it takes 'as a conceptual starting point the construction of Northern 
actors as ... active and generous, and of Southern actors as ... passive and grateful'(Silk 2004: 230). Instead, the potential of responsibility to transcend such binaries emerges from the inter-subjective, situated negotiation of responsibility through encounter (Noxolo et al 2012), one that might involve creativity, struggle and uncertainty as communities and researchers are engaged in practices of mutual learning (Jazeel and McFarlane 2010). As a series of debates around participatory and collaborative fieldwork encounters are beginning to explore, responsible fieldwork should be seen as a shared, situated and relational achievement, and one that involves negotiating a range of elements that might include emotions, skill-sets, intimacies and abilities alongside the aforementioned structural positionings (Kindon et al., 2009, De Leeuw et al 2011).

In this paper, we begin to explore the intersubjective relationalities of responsibility in collaborative undergraduate fieldcourses by focusing in on the ways in which responsibility is relationally enacted in the meeting points where staff, students, partner organizations and local communities are brought together. In order to do so, we use the reflections of the authors -comprising of three academic staff, two students (one with dis/abilities) and the in-country fieldcourse facilitatorinvolved in an undergraduate fieldcourse to Kenya in 2012. In reflecting on the intersubjective responsibilities negotiated in collaborations between staff, students and local partners, we aim to highlight both the possibilities and challenges associated with enacting responsible fieldwork for transcending structurally entrenched NorthSouth power relations, particularly one that is inclusive of differently abled students (Hall et al 2002) and, more widely, scholars and researchers (Horton and Tucker 2013).

\section{Fieldcourse context}

The Kenya fieldcourse was developed by two academic staff in response to Departmental requests at University of Leicester (UoL). The module was designed to offer students the opportunity for fieldwork-based critical engagement with the social, cultural and gendered aspects of environmental justice and grassroots activism; the politics and practices of conservation; and agricultural commodity chain analysis and market integration. Drawing on a postcolonial theoretical 
framework, the approach to these issues was informed by consideration of power relationships embedded into struggles over knowledge, nature and 'development'. In developing the fieldcourse, staff sought to apply a broader collaborative ethic through local partnerships and homestay arrangements that minimized traditional 'look-see' fieldcourses that can retrench the Global South as an object of a Northern academic gaze (Robson 2002). For students, therefore, the course was designed to offer the possibility for immersive, affective and emotional encounters around these themes and as part of pedagogic concerns with personal and academic development.

Practically, the first part of the fieldcourse course was developed in collaboration with Kenya's iconic Green Belt Movement (GBM) who offer 'homestays' with families of local women members in rural Kenya as part of educational, income-generating and empowerment activities. These 'homestays' operate alongside a range of other GBM-supported activities, including local development of tree nurseries, tree planting, bee-keeping and small-scale food production. In recent years GBM have arranged for national and overseas university students, donors, civil society and other environmental study groups to participate in these homestay programmes, though which fees paid to the local host group can then be reinvested into a range of local community development activities. Visitors also typically provide tips and gifts that are pooled and distributed to women participants.

In 2012, and for the first 3 days of the 12 day course, Uol students met with GBM staff in Nairobi, who explained the origins, development, goals and activities of the Movement. They then moved to a village in the Rift Valley to stay with local Movement members in their own homes for the next 4 days. The latter key part of the course was designed to provide students with a degree of immersion (albeit necessarily limited by the duration of the fieldcourse) in local livelihoods and issues and to enable ongoing informal exchanges with host families, to facilitate mutual learning and understanding. Throughout this part of the course UoL staff focused on facilitating students' learning from and with local partners, rather than delivering formal lectures themselves. Instead, presentations and more formal teaching in Nairobi was delivered by GBM staff and invited professors from local universities, 
the latter providing overviews of pertinent aspects of Kenya's colonial experience and more recent history and politics. In the homestay village, students learned both through informal exchanges with host families and activities organised by local GBM staff. These styles of learning continued in the latter part of the fieldcourse, where students proceeded to a camp at Lake Bogoria via a short stay at Lake Naivasha. At Lake Naivasha students were introduced to commodity chain issues through the local flower farms. The days at Lake Bogoria were dedicated to students' small group projects, facilitated by and drawing on UoLs long established work in the area and links with local communities, with the clear proviso that projects must be developed with and be of interest and value to local community partners. On the penultimate day of the fieldcourse, student groups presented the results of their work to an invited audience of local community members and leaders.

Assessment of the course was in three parts: students research reports, based on the projects at Lake Bogoria; student presentations of that work to the community at Lake Bogoria; and a reflective fieldwork diary in which students were required to reflect on the political, environmental and ethical dimensions of fieldwork practice and encounters. The aim of the field diary was to ask students to place themselves within the complex historical networks that connected them in economic, cultural and political relations of power to the collaborating communities in Kenya's Rift Valley.

Negotiating 'responsibility' on a collaborative field-course: tradeoffs, conflicts, resolutions

Geography's colonial disciplinary origins has resulted in a tendency to construct 'the field' as a spatially and temporally discrete space separate from the researchers', thereby framing, reinforcing and inscribing people in the Global South as distanciated 'objects' of research (Driver 2000). Normative, didactic practices of geographic teaching about Africa within post-colonial Northern university settings can reproduce such dichotomies (Robson 2002). For the lecturing staff, destabilizing the othering effects of such distanciated knowledge production was a concern paramount to our collaboration with the Green Belt Movement in the design and planning of the fieldcourse. Not only was our use of the GBM's networks of local 
community groups aimed at decentering university lecturing staff as the primary arbiter of students' learning, a positionality that can exacerbate the production of Africans as distant objects of knowledge (Ansell 2002), but it also purposefully forced students to connect their own everyday lives to those of Kenyans in much more open, intimate and embodied ways. Students were placed with homestay families for 4 days, allowing them to shadow family members as they went about daily business and work, ask questions and engage in informal, conversational interviews. In addition, over the course of the homestays, group lectures were given by GBM staff and women community participants with minimal input from UoL staff. This allowed the specific themes and issues under debate to be negotiated over the week between GBM staff, their community members and the students themselves, empowering participants and students to construct alternative knowledges and meanings about Kenya.

As well as unsettling students' prior experiences, understandings and imaginaries of Kenya, this method of collaborative learning had a range of benefits for the participating community groups, as GBM co-coordinator DM explains:

\begin{abstract}
“Students' experiential field courses are designed to be a fun experience which empowers both hosts and guests ...The purpose is to improve livelihoods of the involved members while creating incentives to preserve ecosystems...[the university] cooperates with the local hosts to improve their economy and protect their local environments. In return the visitors are expected to understand and learn to respect their cultures".
\end{abstract}

For the GBM, this mode of collaborative learning offers material benefits to community participants: income generation from the per diem contributions from homestay visitors that can then be reinvested in other projects. It also offers important intangible benefits, specifically increasing confidence of community members and raising consciousness of their work more widely.

However, despite the centrality of such immersive collaborative encounters, mutual learning and knowledge construction to the fieldcourse as conceived of by GBM and UoL partners, these had to be negotiated not only against disciplinary 
institutional teaching constraints of quantifiable, enumerated, 'learning outcomes' that can close down modes of engaging across distance (Newstead 2009), but also by student expectations and capacities (Ansell 2002). Furthermore, one key omission in debates about collaborative research/ fieldwork is the persistent failure to acknowledge their de facto reliance on the construct of a skilled 'able' researcher (Kindon et al, 2009), whose ability to negotiate multiple responsibilities and demands very often turns on 'the flesh and blood, everyday needs and realities of ... bodies' (Billo and Hiemstra 2013: 322).

In our 2012 fieldcourse, these issues came into sharp focus through the participation of a student with disabilities, specifically Cerebral Palsy, and required further negotiations of sometimes conflicting aspects of responsibility between all parties involved. Cerebral Palsy is used to define 'a range of non-progressive syndromes of posture and motor impairment that results from an insult to the developing central nervous system' (Koman et al 2004: 1619). Student Amita Bhakta has hypotonic Cerebral Palsy. This affects all of her limbs, which impedes her mobility, speech, physical coordination and fine motor movements. She uses a wheelchair over longer distances as she has an unsteady gait and may fall over particularly on uneven ground. Her speech is often unclear, which may have significant impact when talking to others and so, in conducting research interviews, she is not always understood and needs to repeat herself or ask somebody to clarify what she is trying to convey. As a consequence, she required the help of a fieldwork assistant for the duration of the entire field trip. The assistant had a wide range of roles including mobility and practical support, and note-taking.

At a practical level, Amitas' participation necessitated additional health and safety measures and risk assessment concerns, owing to the remoteness of GBM community homestays from medical facilities and the physically challenging nature of the terrain. For lecturing staff, these practical responsibilities for the safety and welfare of all students over-rode to some extent those related to the collaborative goals of the fieldcourse. For Amita specifically this meant avoiding the GBM homestay visit altogether in favour of shorter guided tours of another GBM site in a more accessible location. Whilst these provided opportunities for one-to-one interaction with GBM guides, the homestay experience was not able to be replicated 
in same way and Amita was not able to experience the same day to day interpersonal contact that formed such an important part of collaborative knowledge production for the other students.

Yet, trading off more practical aspects of responsibility against lecturing staff responsibilities towards a co-constitutive pedagogy not only hindered our ability to open all students up to the more interpersonal aspects of knowledge creation, but also at times had the tendency to further reinforce and cement divisions between already-existing dualities of self/other. On the separate programme for Amita, a tour of a settlement had been arranged. Concerned about presenting a good side to the University as paying guests of the GBM, the local guide had put together an intensive alternative programme. With knowledge that the UoL provides a significant economic benefit to the local guides, and in her desire not to offend and to continue the relationship that UoL had with GBM, Amita struggled against her physical disabilities to complete the programme. For her, this necessitated a trade-off against responsibilities to her health:

As the day wore on, I really struggled, not just with my physical state, but with trying to say "stop" ... I wanted to reciprocate [the Guide's] enthusiasm ... but ... I became increasingly exhausted as the tour progressed. But how do I tell...[him]...that I am too tired to continue? There are certain times when I feel ashamed to use my disability to get out of something: this was one of them"

Amita's putting aside of her health to maintain Uol's responsibilities demonstrates the ways that collaborative fieldcourses continue to be emplaced within retrenched, durable, salient circuits of power and privilege, which in this case is the relationships of dependency between the UoL and the GBM. Thus whilst the interpersonal networks and the immersive pedagogies used allowed our students to shift their gaze across North-South distances, in other ways this form of collaboration based on material benefit to communities can also retrench those distances.

Not only can those distances be produced through the material relationships on which our collaborative fieldcourses are founded, but they were also (re)produced through students' inherited expectations. A concern of researchers in 
trying to achieve collaborative research are the personal circumstances, personalities, politics and emotions that mediate their ability to develop a wider ethic of collaborative knowledge production (Billo and Hiemstra 2012). For our students, direct exposure to local voices and perspectives that contrasted with their prior experiences often led to moments of closure, rather than openings, to interpersonal readings across distance. This was particularly the case in relation to gender relations, where many students held up experiences in the GBM homestay context to the universalised models and standards of their own experiences of gender relations. Reflecting on time spent with the women in the homestay AM recalls that

\begin{abstract}
"My enjoyment was however tempered by the realisation of quite how much women in Kenya do for their families. Although the men told us that in Kenya, it is the women that do the kitchen work and the men do the hard-work like digging and providing for the family, that was not my experience. When our UoL group went to go and help dig holes and plant seedlings as part of the GBM (programme), our group and the women from the GBM were all grafting, doing the hard-work; the men meanwhile were standing around talking.... I asked the men "why they were not helping" and was told that they do their work by conversing and working out the tactics"
\end{abstract}

In response, David Mutinda of GBM explained that, "this particular community is a patriarchal community...", and reinforced the importance of students' understanding of local cultural issues and contexts. It is beyond the scope of this paper to unpick these comments/ responses in further detail, but they do much to highlight the dayto-day challenges and experiences of actually practicing mutual learning in a fieldcourse context and of challenging entrenched beliefs and power relations amongst participants.

Kate Moore also observed the discomfort of some female students with patriarchal rural Kenyan society, noting that their preconceptions posed particular challenges for successful engagements with local partners. For example, Kate went through the formalities of introducing female students to the male leaders of the 
village in Bogoria to gain them greater freedom to talk with the women at a later stage. This was interpreted by some of the students as a lack of opportunity to engage directly with the women, rather than as an appropriate way to realise that goal over time within the village hierarchies, whereby male elders expect some consultation before engaging (female) villagers in any activity. These moments of closure were also exacerbated by the short time spent in the field. This example further underscores the ways in trying to achieve collaborative research involves working within and engaging with local power hierarchies and contexts that can conflict with student's own worldviews and expectations.

Managing these durable circuits of power and privilege in shaping or tempering the collaborative goals of the programme rested largely on the differing responsibilities held between UoL staff and GBM staff, particularly in brokering their relationship with each other and between host communities and students. As David explained:

"I have been involved as a link between community members and students for several years, and the major challenge is to clearly understand the expectations of the parties involved and to strive to meet them.....equally important is for the course leader/ lecturer(s) to give clear objectives for the field course..."

Before a group arrives in the homestay communities, GBM guides typically spend three days preparing participant families in how to receive and host guests and a general code of conduct when interacting with visitors. These preparations are critical in allowing community members to open up to study guests. According to David:

"The grassroots (community) groups have no formal training in how to handle a visitor.. therefore the major task is to prepare group members through some training... this also helps to break the cultural shock, making it possible to work with the guest during homestay". 
For local GBM guides, they also receive training, which encourages them to be sensitive to students' body language as well as any stated concerns. In general, and also referring back to Amita's experience, as outlined above, David stated that:

"In many situations (student) participants shy away from speaking their minds and where the guide is not sharp in reading the body language, one can end up in the situation which student $A B$ found herself in-overstretched, but not comfortable to speak about it."

In turn, University staff prepared the students before the fieldcourse in terms of the local contexts, local histories, how to ask questions. Yet even when such training is carried out, the responsibility continued to fall on UoL staff and GBM staff in providing the cultural and historical contexts in which the concerns and questions raised by student throughout the fieldcourse should be interpreted. They discharged these responsibilities primarily by helping students to think through these encounters clashes, to challenge their own pre conceived ideas and try to find some way to accommodate these perspectives, through sustained reflection on their own positionalities.

Towards the end of the fieldcourse, collaboration with local partners in Lake Bogoria to conduct small group projects culminated in the reduction of distance in power between the students and the local community members. Students were able to redress the power relations between them and the local community, through open and honest engagement in their research projects. As Amita explains, through participation in a women's focus group:

I was able to focus my energies purely upon what was unfolding in front of me and letting the women discuss the issues, without having too much of a niggling feeling at the back of my mind as to what they were thinking about me. It was incredibly endearing to see the enthusiasm of the women who were helping me with my project through their accounts of experiencing the issues of water management. ... I was keen to ensure I could provide an open space as possible to work effectively with the women by engaging with them as equal partners in the research. 
As geographers working in such situations, it was imperative for students to recognise the need for open dialogue with those they were working with for the duration of the fieldcourse in order for responsible engagement. Amita's case of working with the focus group reiterated that as a researcher, the open dialogue between her and the women and listening to their views enabled her to become 'an active participant involved in distinctive ways with the shaping of a personal narrative' (Personal Narratives Group, 1989: 201) for each of the women. Rather than to 'give voices', the effective management of various power relations between different bodies ultimately opened up channels of dialogue which facilitated ease of practice in the latter parts of fieldcourse.

\section{Conclusion: towards responsible undergraduate fieldwork in Geography}

Geographers are interested in responsible and collaborative research and fieldwork because it has the potential to challenge historically entrenched power relations that constitute the 'field' as an object of (usually) Western academic gaze. We have focused in this paper on some of the embodied, emotional, affectual, physical and professional registers through which we can take responsibility seriously in geographical pedagogy. If more engaged collaborative scholarship is to be encouraged, then it is important that we recognise the diversity of bodies participating in learning and the challenges inherent in negotiating the trade-offs that arise. As geographers (both academics and students), we should not shy away from more collaborative pedagogies despite the conflicting, overlapping and often difficult responsibilities that it might involve. If we are to use collaborative fieldcourses to open up all students to more diverse ways of reading, thinking and writing about the world, then such a project involves recognising that the negotiation of academic responsibility unfolds contingently in place and between those positioned within different historical, social and economic networks.

Recognising the co-constitutive and relational nature of responsible geographical teaching praxis also draws attention to its inherent uncertainty and partiality, one that requires creative and thoughtful modes of incorporation into the modes of 
learning and assessment in Higher Education. Notwithstanding the difficulty of achieving this within contemporary tuition fee environments, and the concomitant changing set of student expectations and demands around knowledge acquisition, learning and testing that are arising, such a project is essential to unsettling the uneven power relations that continue to define the construction and dissemination of knowledge about the global South.

\section{References:}

Abbott D 2006 Disrupting the 'whiteness' of fieldwork in geography. Singapore Journal of Tropical Geography 27 326-341.

Ansell N 2002 Using films in teaching about Africa Journal of Geography in Higher Education 26 355-368

Billo E and Hiemstra N 2013 Mediating messiness: expanding ideas of flexibility, reflexivity, and embodiment in fieldwork Gender, Place \& Culture 20 313-328.

De Leeuw S, Cameron E and Greenwood, M 2012 Participatory and communitybased research, Indigenous geographies, and the spaces of friendship: A critical engagement The Canadian Geographer 56 180-194.

Driver F 2000 Editorial: Field-work in geography. Transactions of the Institute of British geographers 25: 267-268.

Glass, MR 2014. Encouraging Reflexivity In Urban Geography Fieldwork: Study Abroad Experiences In Singapore And Malaysia. Journal of Geography In Higher Education 38 69-85. 
Hall T, Healey M and Harrison M 2002 Fieldwork and disabled students: discourses of exclusion and inclusion. Transactions of the Institute of British Geographers $27213-31$.

Hammersley, L., Rebecca H. Bilous, Sarah W. James, Adam M. Trau \& Sandie Suchet-Pearson. 2014. Challenging Ideals of Reciprocity In Undergraduate Teaching: The Unexpected Benefits of Unpredictable Cross-Cultural Fieldwork, Journal Of Geography In Higher Education, 38 208-218.

hooks b 1994 Teaching to Transgress: Education as the Practice of Freedom Routledge, London and New York

Hammett D and Sporton D Paying for interviews? Negotiating ethics, power and expectation. Area 44 496-502

Herrick C 2010 Lost in the field: ensuring student learning in the 'threatened' geography fieldtrip Area 42 108-116.

Hill, T. R., Birch-Thomsen, T., Traynor, C. H., De Neergaard, A., \& Bob, U. 2008. Problem-Based, Interdisciplinary Field-Based Courses: Reflections From South African Experiences. South African Geographical Journal, 90(2), 122-133.

Horton J and Tucker F 2013 Disabilities in academic workplaces: experiences of human and physical geographers. Transactions of the Institute of British Geographers. 
Jazeel T and McFarlane C 2010. The limits of responsibility: a postcolonial politics of academic knowledge production. Transactions of the Institute of British Geographers 35 109-24

Kindon S, Pain R and Kesby M 2009 Participatory action research in Kitchin R and Thrift $\mathbf{N}$ eds International encyclopaedia of human geography Elsevier, Oxford 90-95.

Koman AL, Paterson Smitha B, and Shilta JS. 2004. Cerebral Palsy. The Lancet 36 $1619-1631$

Lawson V 2007 Geographies of care and responsibility. Annals of the Association of American Geographers, 97 1-11.

McEwan C and Goodman M 2010 Place geography and the ethics of care: introductory remarks on the geographies of ethics, responsibility and care Ethics, Place and Environment 13 103-12

McEwen, L. 2013. Geography, Community Engagement And Citizenship: Introduction. Journal Of Geography In Higher Education, 37 5-10.

McGuiness M and Simm D 2005 Going Global? Long-Haul Fieldwork In Undergraduate Geography Journal Of Geography In Higher Education, 29 $241-253$

Moseley W 2007 Collaborating in the field, working for change: reflecting on partnerships between academics, development organizations and rural communities in Africa Singapore Journal of Tropical Geography 28 334-47. 
Mostafanezhad M 2013 'Getting in Touch with your Inner Angelina': celebrity humanitarianism and the cultural politics of gendered generosity in volunteer tourism Third world quarterly 34 485-499.

Newstead C 2009 Pedagogy, post-coloniality and care-full encounters in the classroom Geoforum 40 80-90

Silk J 2004 Caring at a distance. Gift theory, aid chains and social movements. Social and Cultural Geography 5 229-251.

Nagar R and Ali F 2003 Collaboration across borders: Moving beyond positionality. Singapore Journal of Tropical Geography 24 356-72.

Noxolo P, Raghuram P and Madge C 2012. Unsettling responsibility: postcolonial interventions Transactions of the Institute of British Geographers 37 418-429.

Pain R et al 2012. Productive tensions-engaging geography students in participatory action research with communities Journal of Geography in Higher Education.

Personal Narratives Group 1989 Whose voice? In Personal Narratives Group (ed.) Interpreting Women's Lives: Feminist Theory and Personal Narratives Indiana University Press, Bloomington 201-203.

Pickerill J 2008 Open access publishing: hypocrisy and confusion in geography Antipode 40 710-23 
Raghuram P and Madge C 2006. Towards a method for postcolonial development geography? Possibilities and challenges. Singapore Journal of Tropical Geography 27 270-88.

Robson E 2002. An unbelievable academic and personal experience': issues around teaching undergraduate field courses Africa. Journal of Geography in Higher Education 26 327-44.

Robson, E., Willis, K., \& Holloway, R. 2013. Field Courses In The Global South For Geography, Earth And Environmental Science Students In UK Higher Education. Rport of the Higher Education Authority, accessed 12th September 2014, available at http://wwwnew1.heacademy.ac.uk/assets/documents/disciplines/GEES/GEES-

Fieldcourse.pdf

Sidaway JD 1992 In other worlds: on the politics of research by 'First World' geographers in the 'Third World'. Area, 403-408.

Valentine G 2005 Geography and ethics: moral geographies? Ethical commitment in research and teaching Progress in Human Geography 29 483-487

Winlow, H., Simm, D., \& Haslett, S. 2007. Extended Work-Related Placements In Developing Countries: Supporting Remote Learning And Assessment. Planet 18 28-32. 